\title{
Planned FY19 Creep and Fatigue Design Curve Testing of Alloy 709 Base Metal
}

\section{Approved for public release.} Distribution is unlimited.

Yanli Wang

T.-L. Sham

September 2019 


\section{DOCUMENT AVAILABILITY}

Reports produced after January 1, 1996, are generally available free via US Department of Energy (DOE) SciTech Connect.

Website www.osti.gov

Reports produced before January 1, 1996, may be purchased by members of the public from the following source:

National Technical Information Service

5285 Port Royal Road

Springfield, VA 22161

Telephone 703-605-6000 (1-800-553-6847)

TDD 703-487-4639

Fax 703-605-6900

E-mail info@ntis.gov

Website http://classic.ntis.gov/

Reports are available to DOE employees, DOE contractors, Energy Technology Data Exchange representatives, and International Nuclear Information System representatives from the following source:

Office of Scientific and Technical Information

PO Box 62

Oak Ridge, TN 37831

Telephone 865-576-8401

Fax 865-576-5728

E-mail reports@osti.gov

Website http://www.osti.gov/contact.html

This report was prepared as an account of work sponsored by an agency of the United States Government. Neither the United States Government nor any agency thereof, nor any of their employees, makes any warranty, express or implied, or assumes any legal liability or responsibility for the accuracy, completeness, or usefulness of any information, apparatus, product, or process disclosed, or represents that its use would not infringe privately owned rights. Reference herein to any specific commercial product, process, or service by trade name, trademark, manufacturer, or otherwise, does not necessarily constitute or imply its endorsement, recommendation, or favoring by the United States Government or any agency thereof. The views and opinions of authors expressed herein do not necessarily state or reflect those of the United States Government or any agency thereof. 
Materials Science and Technology Division

PLANNED FY19 CREEP AND FATIGUE DESIGN CURVE TESTING OF ALLOY 709 BASE METAL

\author{
Authors \\ Yanli Wang \\ T.-L. Sham ${ }^{\dagger}$
}

†Argonne National Laboratory

Date Published: September 2019

Prepared by

OAK RIDGE NATIONAL LABORATORY

Oak Ridge, TN 37831-6283

managed by

UT-BATTELLE, LLC

for the

US DEPARTMENT OF ENERGY

under contract DE-AC05-00OR22725 



\section{CONTENTS}

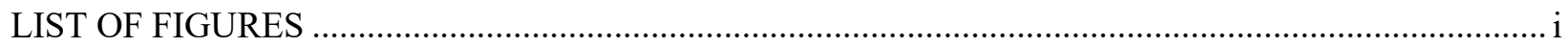

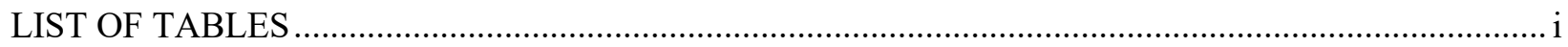

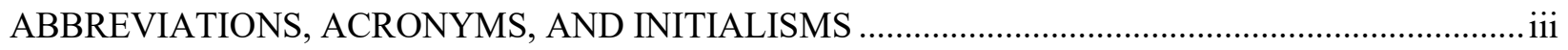

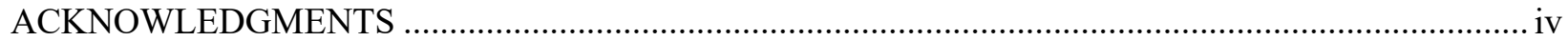

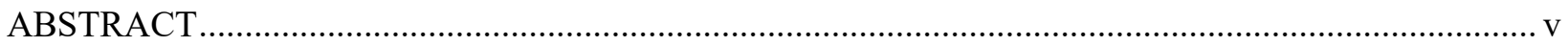

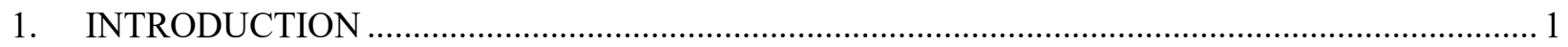

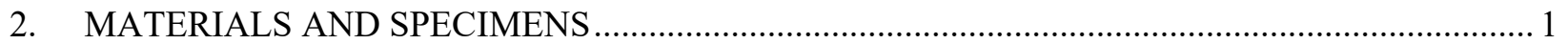

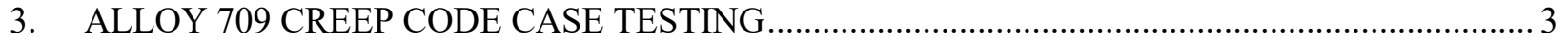

3.1 ORNL ALLOY 709 CREEP CODE CASE TESTING PLAN AND STATUS ....................... 3

3.2 SUMMARY OF THE CREEP RUPTURE TESTS OF ESR WITH S/A AT $1100^{\circ} \mathrm{C} \ldots \ldots \ldots \ldots . . . . .5$

4. INITIATION OF FATIGUE TESTING ON ALLOY 709 ....................................................... 8

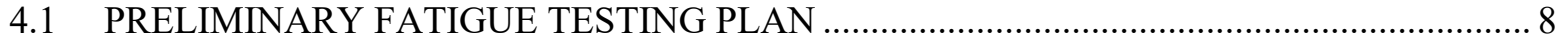

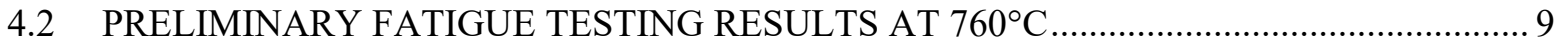

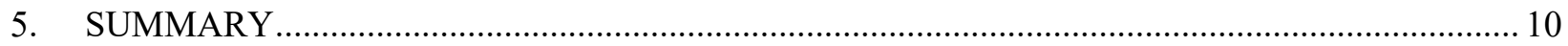

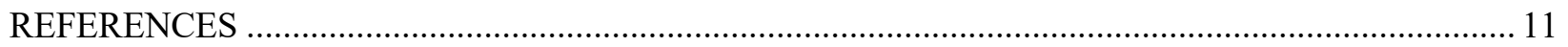

\section{LIST OF FIGURES}

Fig. 1. Creep specimen geometry for Alloy 709 Code Case testing at ORNL. Units are in inches............. 2

Fig. 2. Standard creep-fatigue specimen geometry. Units are in inches............................................... 2

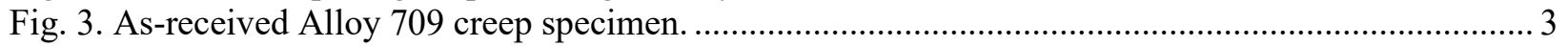

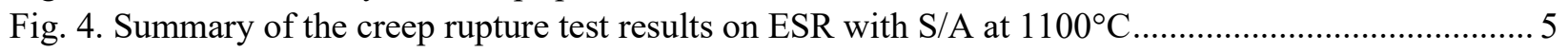

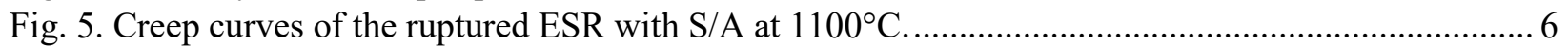

Fig. 5. Creep curves of the ruptured ESR with S/A at $1100^{\circ} \mathrm{C}$ (continued).......................................... 7

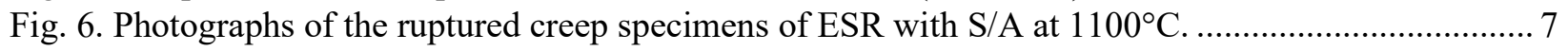

Fig. 6. Photographs of the ruptured creep specimens of ESR with S/A at $1100{ }^{\circ} \mathrm{C}$ (continued)................ 8

Fig. 7. Strain-controlled fatigue loading profile for one cycle .............................................................. 8

Fig. 8. As-received Alloy 709 fatigue specimen.................................................................................

Fig. 9. Maximum and minimum stresses of fatigue tests on ESR specimens with S/A at $1100^{\circ} \mathrm{C}$ at $760^{\circ} \mathrm{C}$ at strain ranges of $1 \%$ (a), $0.6 \%$ (b), $0.4 \%$ (c), and $0.3 \%$ (d). The black and blue lines in (a) and (b) are duplicate tests of the same conditions. .................................................... 10

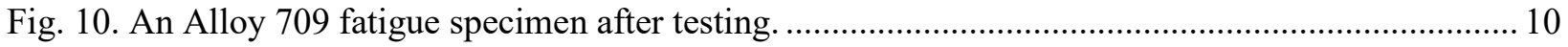

\section{LIST OF TABLES}

Table 1. Chemical compositions of Alloy 709 (wt \%) ......................................................................... 2

Table 2. Summary of the Alloy 709 creep Code Case testing matrix....................................................... 3

Table 3. Creep tests and status of Alloy $709 \mathrm{ESR}$ with S/A at $1100^{\circ} \mathrm{C}$ at ORNL................................. 4

Table 4. Creep tests and status of Alloy 709 AOD with S/A at $1100^{\circ} \mathrm{C}$ at ORNL................................. 5

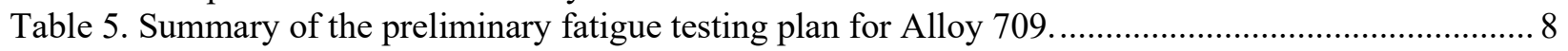

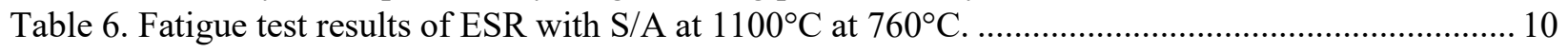




\section{ABBREVIATIONS, ACRONYMS, AND INITIALISMS}

AOD

ART

ANL

ASME

ASTM

DOE

EL

ESR

INL

LVDT

MCR

NE

ORNL

$\mathrm{S} / \mathrm{A}$

RA

TC argon-oxygen-decarburization

Advanced Reactor Technologies

Argonne National Laboratory

American Society of Mechanical Engineers

American Society for Testing and Materials

Department of Energy

elongation

electroslag remelt

Idaho National Laboratory

Linear variable differential transformer

minimum creep rate

Office of Nuclear Energy

Oak Ridge National Laboratory

solution annealing

reduction of area

thermocouple 


\section{ACKNOWLEDGMENTS}

This research was sponsored by the US Department of Energy (DOE), Office of Nuclear Energy (NE), under contract No. DE-AC02-06CH11357 with Argonne National Laboratory, managed and operated by UChicago Argonne LLC, and under contract DE-AC05-00OR22725 with Oak Ridge National Laboratory (ORNL), managed and operated by UT-Battelle LLC. Programmatic direction was provided by the Office of Nuclear Reactor Deployment of DOE NE.

The authors gratefully acknowledge the support provided by Brian Robinson, DOE-NE, Federal Manager, Fast Reactors Campaign, Advanced Reactor Technologies (ART) Program; Sue Lesica, Federal Manager, Advanced Materials, ART Program; and Robert Hill of Argonne National Laboratory, National Technical Director, Fast Reactors Campaign, ART Program.

The authors also wish to thank ORNL staff member C. Shane Hawkins and technical intern Christina Padilla for their technical support. The authors gratefully appreciate ORNL staff member Hong Wang in initiating the creep Code Case testing on Alloy 709 and reviewing this report. The time spent by Donald Erdman III of ORNL reviewing this report is also acknowledged. 


\begin{abstract}
This report summarizes the status of planned FY 2019 creep and fatigue testing of the first commercial heat of Alloy 709 base metal at Oak Ridge National Laboratory (ORNL).

A comprehensive master creep testing matrix was generated to support the ASME code qualification of Alloy 709. The testing activities and research are carried out at Argonne National Laboratory, Idaho National Laboratory and ORNL. ORNL was tasked to carry out a subset of the creep Code Case testing matrix for electroslag remelt (ESR) with solution annealing (S/A) at $1100^{\circ} \mathrm{C}$ in FY 2019. In this reporting cycle, 25 creep tests were started and 9 of them produced rupture data. The remaining 16 tests of ESR with $\mathrm{S} / \mathrm{A}$ at $1100^{\circ} \mathrm{C}$, along with 6 long-term creep tests of argon-oxygen-decarburization with S/A at $1100^{\circ} \mathrm{C}$, are ongoing.

A preliminary plan for fatigue testing was formulated. Specimens were machined from ESR with S/A at $1100^{\circ} \mathrm{C}$ and testing was initiated at $760^{\circ} \mathrm{C}$.

This report fulfills the level 3 deliverable for milestone M3AT-19OR020502061, under work package AT-19OR02050206 "A709 Code Case Testing_ORNL."
\end{abstract}




\section{INTRODUCTION}

Because of the significant enhancement in mechanical properties of the austenitic stainless steel Alloy 709 relative to $316 \mathrm{H}$ stainless steel, which is a reference construction material for sodium fast reactor systems, code qualification of Alloy 709 was recommended in FY 2014. A comprehensive plan for the development of a $500,000 \mathrm{~h}, 760^{\circ} \mathrm{C}$ ASME Code Case and the resolution of structural integrity issues identified by the Nuclear Regulatory Commission (NRC) for Alloy 709 was developed in FY 2015. The maximum use temperature of $760^{\circ} \mathrm{C}$ also draws interest from molten salt reactor vendors in the potential use of Alloy 709 in their designs.

The execution of the Phase I plan was initiated in FY 2016. Creep testing frames at Argonne National Laboratory (ANL), Idaho National Laboratory (INL) and Oak Ridge National Laboratory (ORNL) underwent upgrading and refurbishment to support the generation of creep rupture data for the Alloy 709 Code Case. In collaboration with material vendor G.O. Carlson Inc. of Pennsylvania, the Advanced Reactor Technologies (ART) program successfully scaled the production of Alloy 709 from a laboratory heat of $500 \mathrm{lb}$ to a commercial heat of 45,000 lb. The master heat of Alloy 709, heat number 58776, was processed under various processing conditions: argon-oxygen-decarburization (AOD), electroslag remelting (ESR), ESR with subsequent homogenization (ESR-homogenized), and three different solution annealing (S/A) temperatures. The fabrication procedures for the first commercial heat of Alloy 709 hotrolled plates are summarized in Natesan et al. 2017.

The Alloy 709 plates produced under these different processing conditions were tested for creep, fatigue, and creep-fatigue under selected conditions to screen for the preferred processing condition. Both AOD with S/A at $1100^{\circ} \mathrm{C}$ and ESR with S/A at $1100^{\circ} \mathrm{C}$ showed good microstructure and combined hightemperature mechanical properties (McMurtrey 2018). In FY 2018, long-term creep tests were initiated at ORNL for plates produced by AOD with S/A at $1100^{\circ} \mathrm{C}$ under six different test conditions, at temperatures of 550 to $800^{\circ} \mathrm{C}$ and stresses of 38 to $309 \mathrm{MPa}$, to a target rupture time of $60,000 \mathrm{~h}$. This activity is documented in Wang et al. 2018.

The test effort for the comprehensive creep test matrix developed to support the preliminary, 100,000 hr, 3000,000 $\mathrm{hr}$ and 500,000 hr Alloy 709 Code Cases was split among ANL, INL and ORNL. ESR with S/A $1100{ }^{\circ} \mathrm{C}$ was added to the intermediate and long-term testing effort in FY 2019. This report documents the status of the planned FY 2019 creep testing and the initiation of fatigue design curve testing on ESR base metal with S/A at $1100^{\circ} \mathrm{C}$ at ORNL.

\section{MATERIALS AND SPECIMENS}

The Alloy 709 plates produced by AOD had a subheat number of \#58776-4 and those with S/A at $1100^{\circ} \mathrm{C}$ had a lot ID of \#58776-4B. The ESR and ESR-homogenized plates had a subheat number of \#58776-3R, and ESR plates with S/A at $1100^{\circ} \mathrm{C}$ had a lot ID of \#58776-3RBB. The chemical compositions of the AOD and ESR with $\mathrm{S} / \mathrm{A}$ at $1100^{\circ} \mathrm{C}$ are listed in Table 1.

The creep specimen was designed to have 0.375 in gage diameter with a nominal gage length of 1.875 in. A drawing of the creep specimen is shown in Fig. 1. The standard fatigue specimen had a 0.25 in gage diameter and a 0.75 in gage length (Fig. 2). 
Table 1. Chemical compositions of Alloy 709 (wt \%).

\begin{tabular}{c|c|c|c|c|c|c|c|c|c|c|c|c|c|c|c}
\hline $\begin{array}{c}\text { Heat } \\
\text { No. }\end{array}$ & $\mathbf{C}$ & $\mathbf{C r}$ & $\mathbf{C o}$ & $\mathbf{N i}$ & $\mathbf{M n}$ & $\mathbf{M o}$ & $\mathbf{N}$ & $\mathbf{S i}$ & $\mathbf{P}$ & $\mathbf{S}$ & $\mathbf{T i}$ & $\mathbf{N b}$ & $\mathbf{A l}$ & $\mathbf{B}$ & $\mathbf{C u}$ \\
\hline $\begin{array}{c}\text { \#58776- } \\
\text { 4B }\end{array}$ & 0.07 & 19.93 & 0.02 & 24.98 & 0.91 & 1.51 & 0.148 & 0.44 & 0.014 & $<.000$ & 0.04 & 0.26 & 0.02 & 0.0045 & 0.06 \\
\hline $\begin{array}{c}\text { \#58776- } \\
\text { 3RBB }\end{array}$ & 0.066 & 20.05 & 0.02 & 25.14 & 0.90 & 1.51 & 0.152 & 0.38 & 0.014 & 0.001 & 0.01 & 0.26 & 0.02 & 0.0030 & 0.06 \\
\hline
\end{tabular}

Balance is Fe.

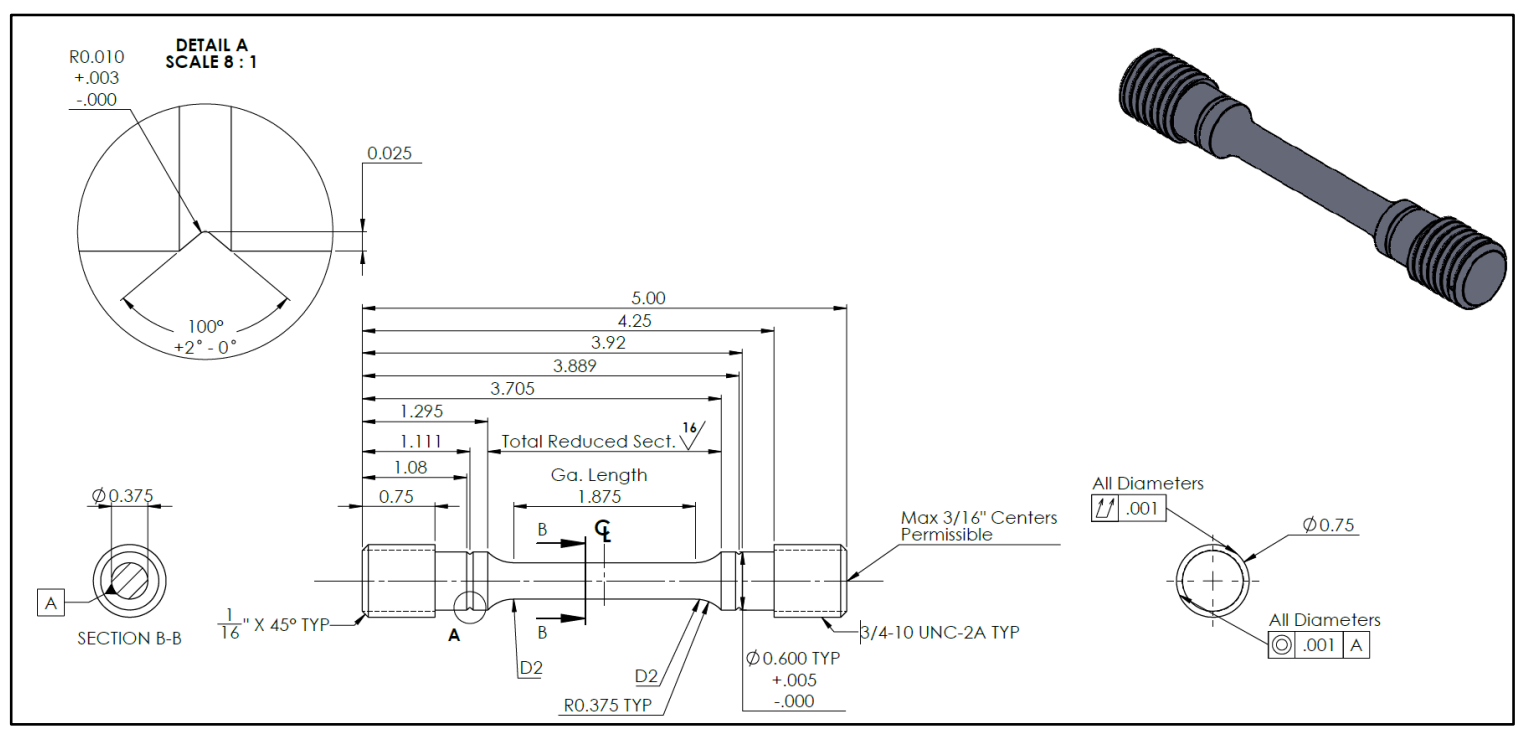

Fig. 1. Creep specimen geometry for Alloy 709 Code Case testing at ORNL. Units are in inches.

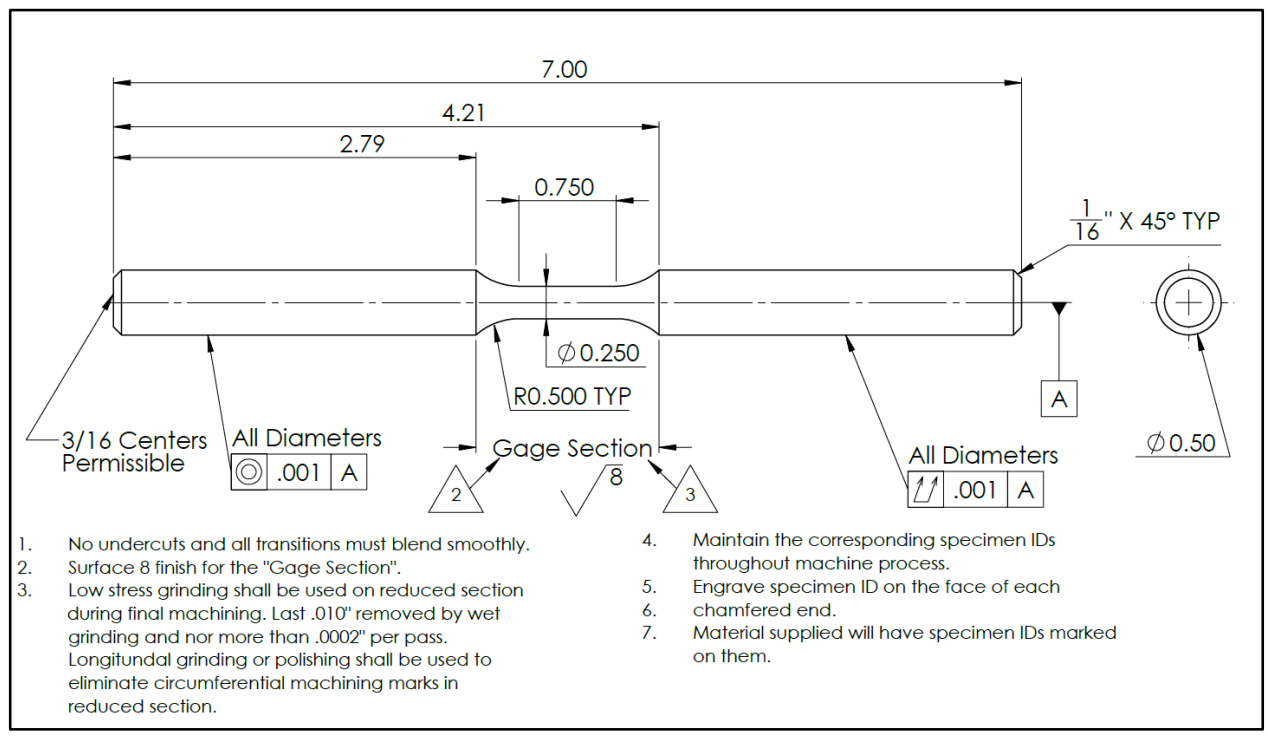

Fig. 2. Standard creep-fatigue specimen geometry. Units are in inches. 


\section{ALLOY 709 CREEP CODE CASE TESTING}

\subsection{ORNL ALLOY 709 CREEP CODE CASE TESTING PLAN AND STATUS}

A comprehensive master creep testing matrix for Alloy 709 Code Case testing was generated which involved a total of 68 creep tests of ESR with S/A at $1100^{\circ} \mathrm{C}$. The testing activities and research to support the qualification of the Alloy 709 are carried out at ANL, INL, and ORNL. The creep testing matrix is to generate data for preliminary, $100,000 \mathrm{~h}, 300,000 \mathrm{~h}$, and 500,000 h Code Cases. The creep Code Case testing matrix is summarized in Table 2. The creep testing covers a temperature range of 525$950^{\circ} \mathrm{C}$ and stress levels of $15-380 \mathrm{MPa}$.

Table 2. Summary of the Alloy 709 creep Code Case testing matrix.

\begin{tabular}{c|c|c|c|c|c}
\hline $\begin{array}{c}\text { Target Code } \\
\text { Case }\end{array}$ & $\begin{array}{c}\text { Predicted life, } \\
(\mathbf{h})\end{array}$ & $\begin{array}{c}\text { Temp. } \\
\left({ }^{\circ} \mathbf{C}\right)\end{array}$ & $\begin{array}{c}\text { Stress, } \\
\text { MPa }\end{array}$ & Labs involved & $\begin{array}{c}\text { Planned } \\
\text { no. of } \\
\text { tests }\end{array}$ \\
\hline Preliminary & $500-10,000$ & $575-950$ & $21-355$ & $\begin{array}{c}\text { Argonne/INL/ } \\
\text { ORNL }\end{array}$ & 36 \\
\hline $100,000 \mathrm{~h}$ & $11,000-24,000$ & $550-950$ & $15-380$ & Argonne/INL & 16 \\
\hline $300,000 \mathrm{~h}$ & $25,000-68,000$ & $550-925$ & $15-330$ & ORNL & 11 \\
\hline $500,000 \mathrm{~h}$ & $91,000-109,000$ & $525-800$ & $35-355$ & ORNL & 5 \\
\hline
\end{tabular}

ORNL was tasked to carry out a subset of the creep Code Case testing matrix of ESR with S/A at $1100^{\circ} \mathrm{C}$ in FY 2019. The test parameters and status of the 29 creep tests are summarized in Table 3. A picture of one of the as-received creep specimens is shown in Fig. 3.

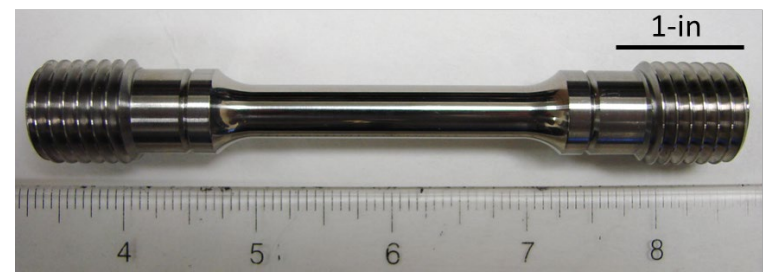

Fig. 3. As-received Alloy 709 creep specimen.

The testing procedure followed ASTM E 139-11, Standard Test Methods for Conducting Creep, CreepRupture, and Stress-Rupture Tests of Metallic Materials. The creep tests were arranged to best utilize the individual creep machine capacity and estimated testing time. A major effort was required for calibration of the machines, setting up the tests, and loading the specimens to the test frame. Creep tests began for 25 specimens, and 9 of them had ruptured at the time of this report. The remaining four tests were delayed by specimen machining and will be carried out when additional creep specimens are machined and delivered.

The six long-term creep tests initiated in FY 2018 are listed in Table 4. The details of these tests are documented in Wang et al. 2018. These tests are ongoing, with accumulated creep time of approximately $8,000 \mathrm{~h}$ for each test as of September 1, 2019. 
Table 3. Creep tests and status of Alloy $709 \mathrm{ESR}$ with $\mathrm{S} / \mathrm{A}$ at $1100^{\circ} \mathrm{C}$ at ORNL.

\begin{tabular}{|c|c|c|c|c|c|}
\hline $\begin{array}{l}\text { Test number } \\
\text { (TN) }\end{array}$ & $\begin{array}{l}\text { Creep } \\
\text { frame }\end{array}$ & $\begin{array}{l}\text { Stress, } \\
\text { MPa }\end{array}$ & $\begin{array}{c}\text { Temperature, } \\
{ }^{\circ} \mathrm{C}\end{array}$ & TC type & status \\
\hline 34162 & 5 & 355 & 525 & $\mathrm{~K}$ & Ongoing \\
\hline 34163 & 6 & 330 & 550 & K & Ongoing \\
\hline 34182 & 516 & 285 & 550 & K & Ongoing \\
\hline 34183 & 517 & 285 & 575 & K & Ongoing \\
\hline 34130 & 94 & 200 & 600 & K & Ongoing \\
\hline 34110 & 307 & 175 & 625 & K & Ongoing \\
\hline 34113 & 306 & 155 & 625 & $\mathrm{~K}$ & Ongoing \\
\hline 34111 & 305 & 90 & 700 & $\mathrm{~K}$ & Ongoing \\
\hline 34161 & 301 & 80 & 700 & K & Ongoing \\
\hline 34112 & 304 & 80 & 725 & K & Ongoing \\
\hline 34133 & 78 & 80 & 775 & K & Ruptured \\
\hline 34132 & 80 & 80 & 800 & $\mathrm{~S}$ & Ruptured \\
\hline 34184 & 518 & 60 & 750 & K & Ongoing \\
\hline 34131 & 81 & 60 & 825 & $\mathrm{~S}$ & Ruptured \\
\hline 34160 & 64 & 50 & 850 & K & Ruptured \\
\hline 34242 & 511 & 40 & 800 & K & Ongoing \\
\hline 34181 & 510 & 40 & 875 & K & Ruptured \\
\hline 34265 & 64 & 35 & 800 & K & Ongoing \\
\hline TBD & TBD & 35 & 825 & TBD & To be tested \\
\hline 34244 & 80 & 35 & 875 & $\mathrm{~S}$ & Ruptured \\
\hline 34278 & 83 & 35 & 900 & $\mathrm{~S}$ & Ruptured \\
\hline 34277 & 79 & 35 & 925 & $\mathrm{~S}$ & Ruptured \\
\hline 34242 & 81 & 27 & 925 & $\mathrm{~S}$ & Ruptured \\
\hline 34274 & 76 & 21 & 875 & $S$ & Ongoing \\
\hline 34275 & 77 & 15 & 925 & $\mathrm{~S}$ & Ongoing \\
\hline 34245 & 89 & 50 & 825 & $\mathrm{~K}$ & Ongoing \\
\hline TBD & TBD & 40 & 850 & TBD & To be tested \\
\hline TBD & TBD & 27 & 900 & TBD & To be tested \\
\hline TBD & TBD & 21 & 925 & TBD & To be tested \\
\hline
\end{tabular}

* TBD: to be determined. 
Table 4. Creep tests and status of Alloy 709 AOD with S/A at $1100^{\circ} \mathrm{C}$ at ORNL.

\begin{tabular}{c|c|c|c|c}
\hline Test number & $\begin{array}{c}\text { Creep } \\
\text { frame }\end{array}$ & $\begin{array}{c}\text { Stress, } \\
\text { MPa }\end{array}$ & $\begin{array}{c}\text { Temperature, } \\
{ }^{\circ} \mathbf{C}\end{array}$ & Status \\
\hline 33629 & 88 & 309 & 550 & Ongoing \\
\hline 33630 & 93 & 204 & 600 & Ongoing \\
\hline 33631 & 91 & 134 & 650 & Ongoing \\
\hline 33632 & 95 & 88 & 700 & Ongoing \\
\hline 33635 & 302 & 38 & 800 & Ongoing \\
\hline 33636 & 303 & 58 & 750 & Ongoing \\
\hline
\end{tabular}

\subsection{SUMMARY OF THE CREEP RUPTURE TESTS OF ESR WITH S/A AT $1100^{\circ} \mathrm{C}$}

Nine short-term creep rupture test data sets were obtained during this reporting period. The testing results - rupture time, measured elongation (EL), reduction of area (RA), and minimum creep rate (MCR) - are summarized in Fig. 4. The creep curves for the nine ruptured specimens are presented in Fig. 5 and photographs of the ruptured specimens are shown in Fig. 6. All nine tests showed good creep ductility with elongation between 35.7 and $80.3 \%$ and RA between 65.5 and $81.5 \%$.
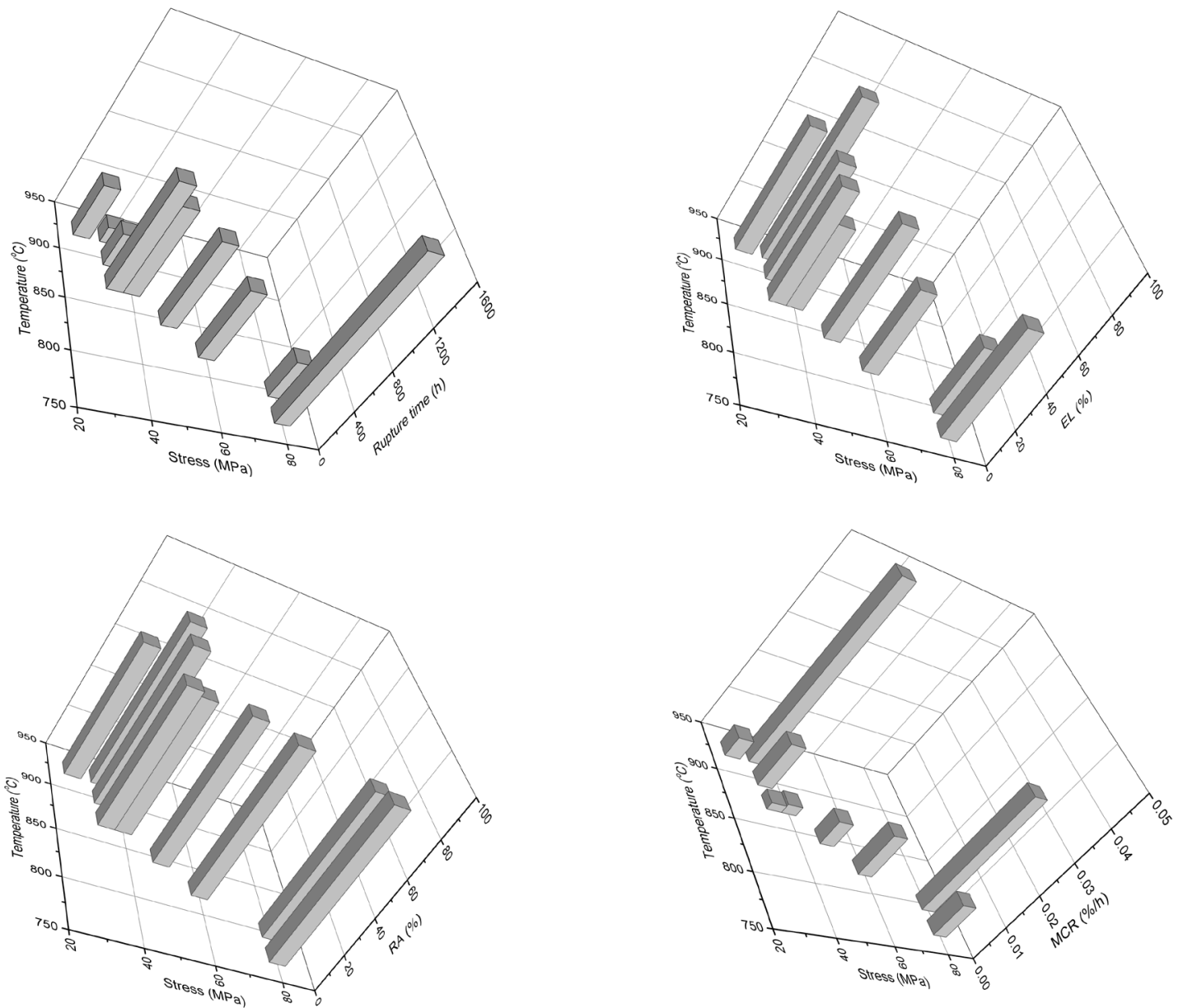

Fig. 4. Summary of the creep rupture test results on ESR with $\mathrm{S} / \mathrm{A}$ at $1100^{\circ} \mathrm{C}$ 
Due to the large elongation for these tests, the strain signals from the Linear Variable Differential Transformers (LVDTs) ran out of range before the rupture. The LVDTs were reset during the test to continue to capture creep deformation. During the adjustment of the LVDTs, the creep tests were not interrupted, but the strains may have interruptions (shown as the gaps in the creep curve plots), depending on the timing of the LVDT reset process. In some cases, during the tertiary creep stage, the LVDT missed the data points close to rupture, the post-test measurements are used as the total creep strain ( shown as the last single data point on the creep curve plots).
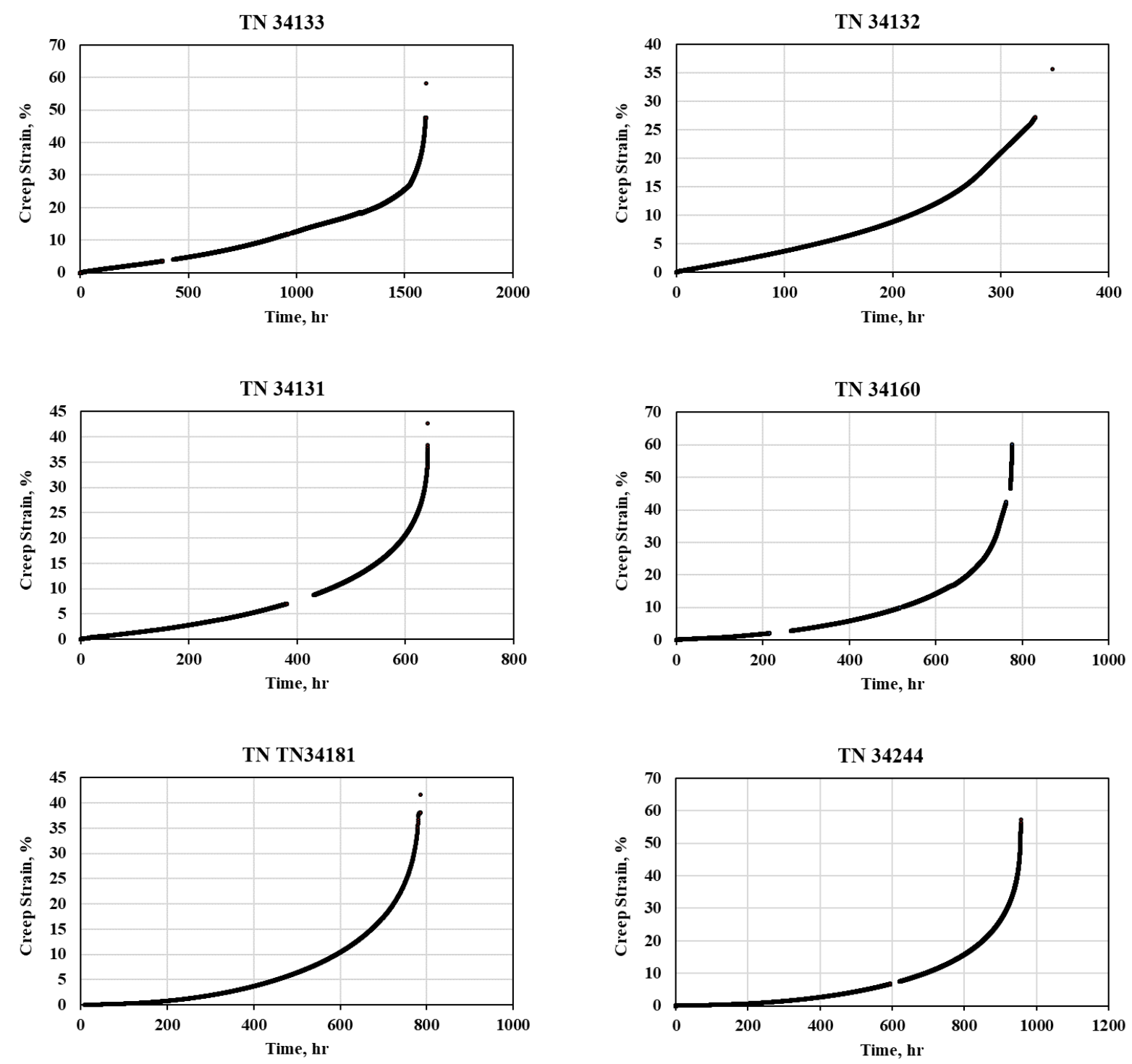

Fig. 5. Creep curves of the ruptured ESR with $\mathrm{S} / \mathrm{A}$ at $1100^{\circ} \mathrm{C}$. 

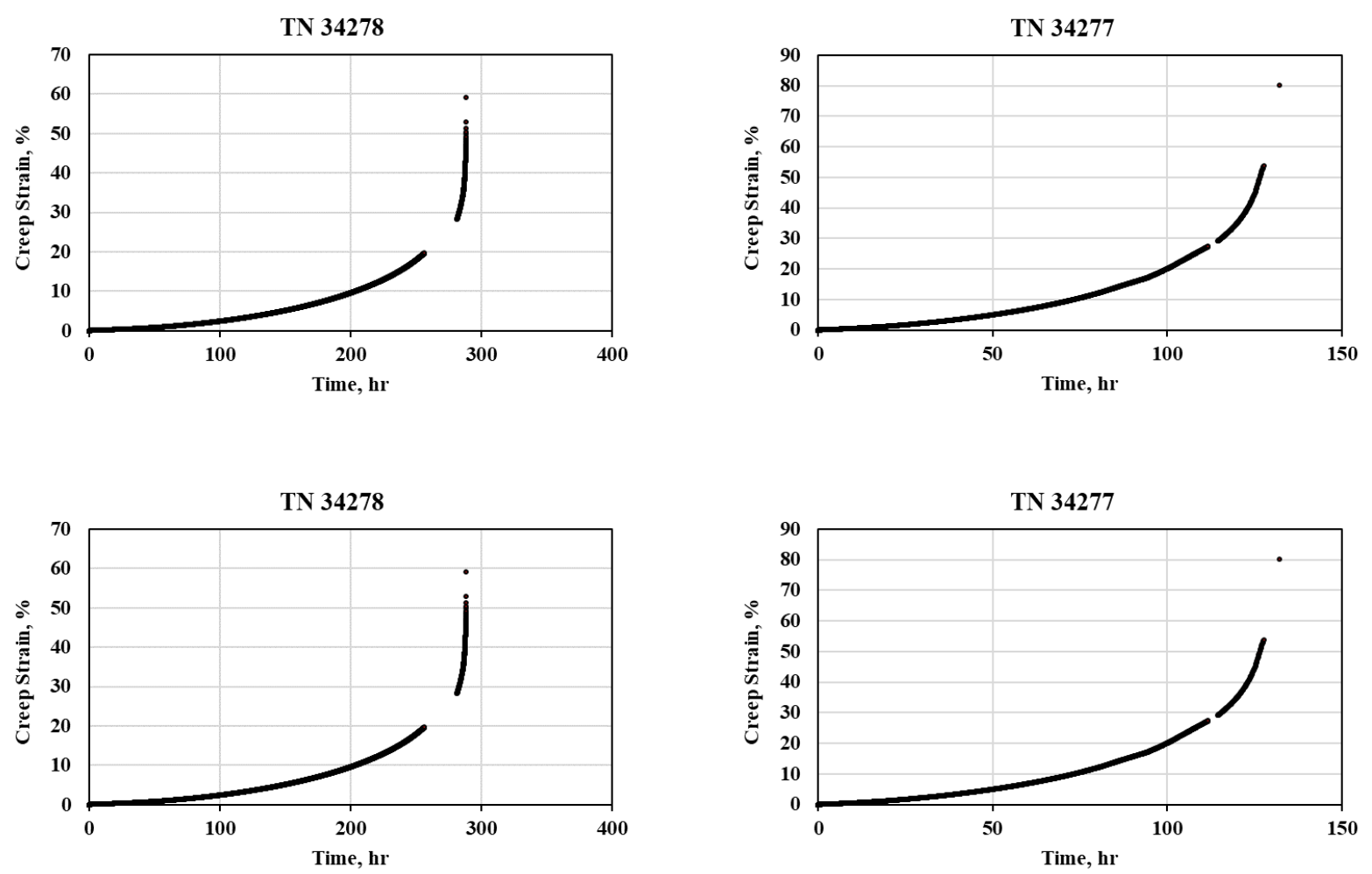

TN 34242

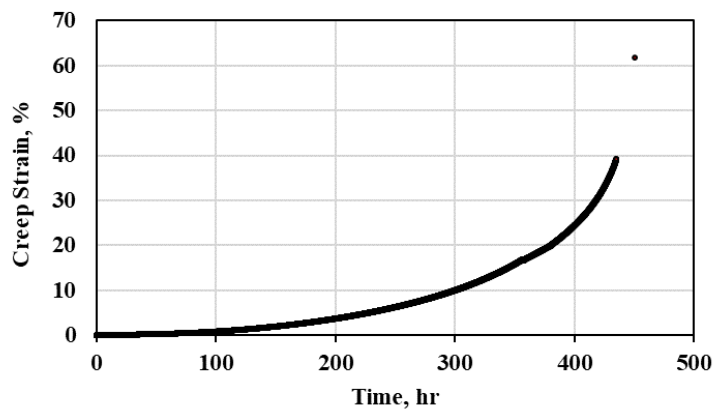

Fig. 5. Creep curves of the ruptured ESR with S/A at $1100{ }^{\circ} \mathrm{C}$ (continued).
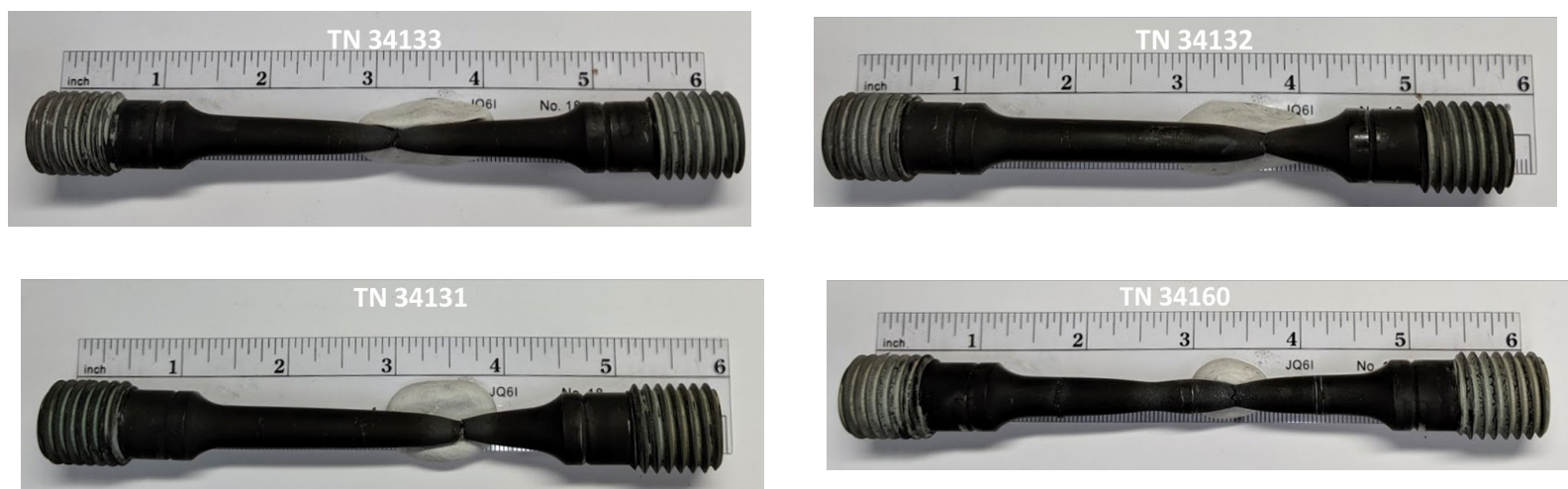

Fig. 6. Photographs of the ruptured creep specimens of ESR with $\mathrm{S} / \mathrm{A}$ at $1100^{\circ} \mathrm{C}$. 

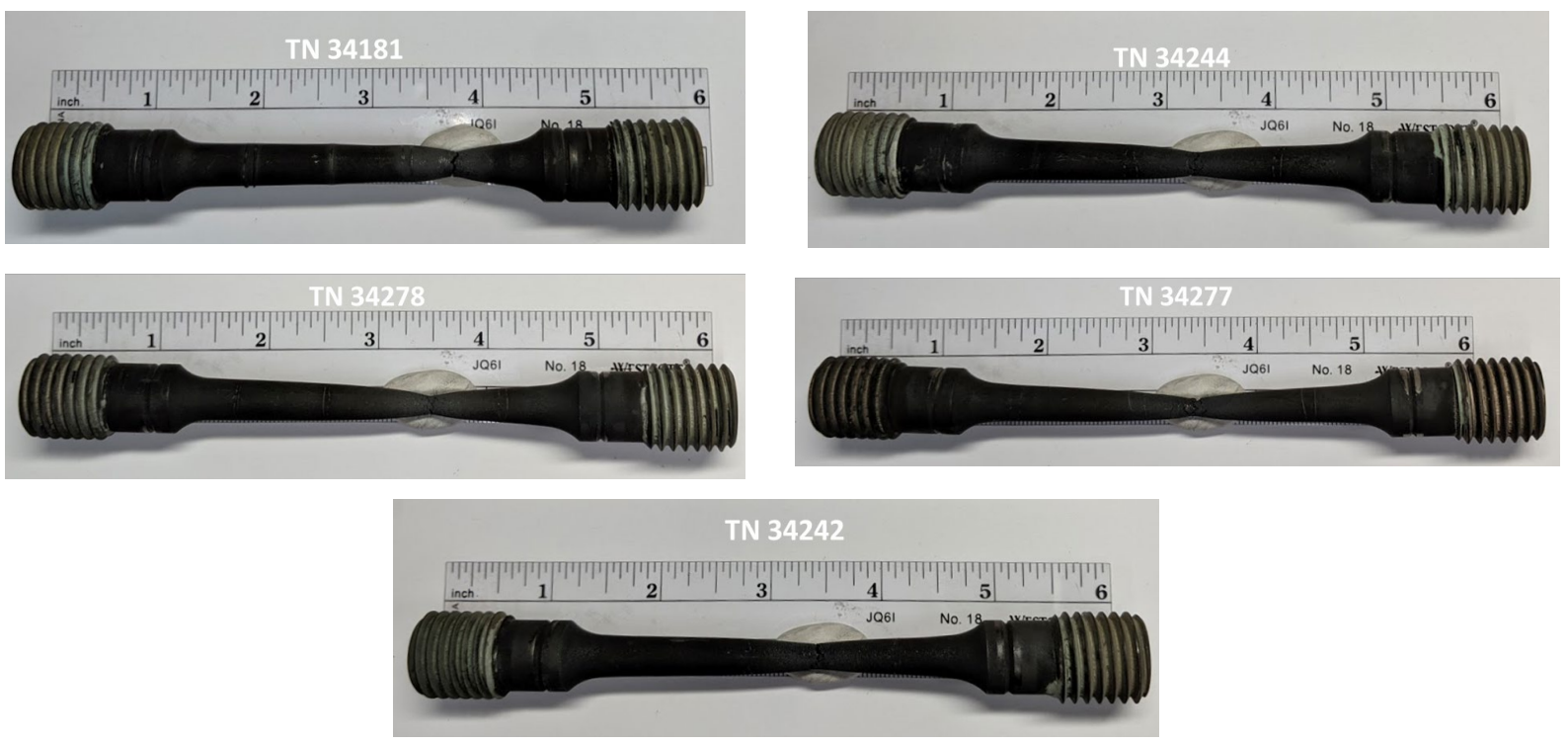

Fig. 6. Photographs of the ruptured creep specimens of ESR with S/A at $1100{ }^{\circ} \mathrm{C}$ (continued).

\section{INITIATION OF FATIGUE TESTING ON ALLOY 709}

\subsection{PRELIMINARY FATIGUE TESTING PLAN}

A preliminary testing plan for development of Alloy 709 fatigue design curves has been generated to cover temperatures of $500,500,550,650$ and $760^{\circ} \mathrm{C}$ and strain range from $3 \%$ to $0.2 \%$. this plan is summarized in Table 5. Testing will follow a strain-controlled fatigue standard (i.e., ASTM E606). The strain rate will be controlled at $1 \mathrm{E}-3 \mathrm{~s}^{-1}$. The loading is a triangular shape with a fully reversed profile, i.e., a loading ratio of $\mathrm{R}=-1$ (schematically shown in Fig. 7). Two or three duplicate tests are planned. It is expected that the testing at the low strain range of $0.2 \%$ will result in a large number of cycles and hence a long test duration; only two duplicates are planned at this strain range.

Table 5. Summary of the preliminary fatigue testing plan for Alloy 709.

\begin{tabular}{l|c|c|c|c|c}
\hline Material & $\begin{array}{c}\text { Temperatures, } \\
{ }^{\circ} \mathbf{C}\end{array}$ & Strain range, $\%$ & Strain rate, $\mathbf{s}^{-\mathbf{1}}$ & R ratio & Duplicate \\
\hline $\begin{array}{l}\text { ESR with S/A } \\
\text { at } 1100^{\circ} \mathrm{C}\end{array}$ & $\begin{array}{c}500,550,650, \\
760\end{array}$ & $3,2,1,0.6,0.4,0.3,0.2$ & $1 \mathrm{E}-3$ & -1 & $2-3$ \\
\hline
\end{tabular}

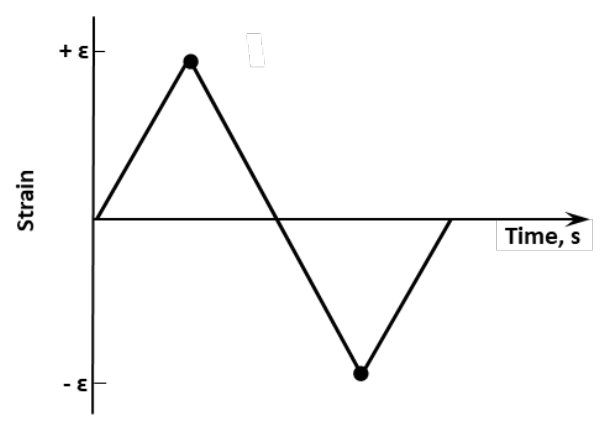

Fig. 7. Strain-controlled fatigue loading profile for one cycle. 
The specimen design used a standard fatigue specimen per ASTM E606. A photo of the as-received fatigue specimen machined from ESR with $\mathrm{S} / \mathrm{A}$ at $1100^{\circ} \mathrm{C}$ is shown in Fig. 8.

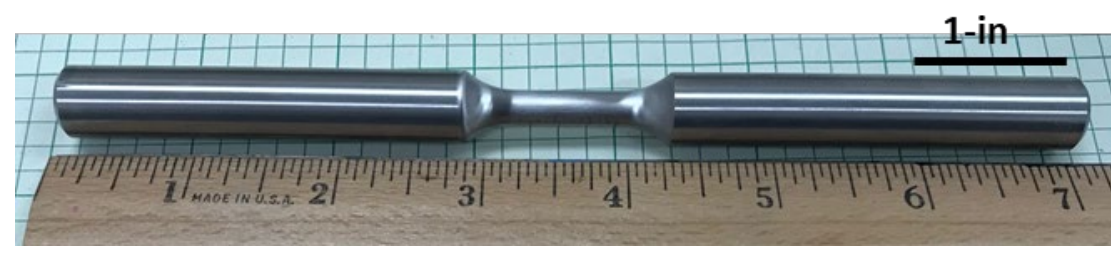

Fig. 8. As-received Alloy 709 fatigue specimen.

\subsection{PRELIMINARY FATIGUE TESTING RESULTS AT $760^{\circ} \mathrm{C}$}

The fatigue testing of specimens from ESR plates with S/A at $1100^{\circ} \mathrm{C}$ was initiated at $760^{\circ} \mathrm{C}$ in $\mathrm{FY} 2019$. Six tests were completed at strain ranges of $1 \%, 0.6 \%, 0.4 \%$, and $0.3 \%$. The maximum and minimum stresses as a function of the applied cycles are plotted in Fig. 9. Two fatigue tests were performed at the $1 \%$ and $0.6 \%$ strain ranges, and the results were consistent between the two duplicates for both strain ranges.

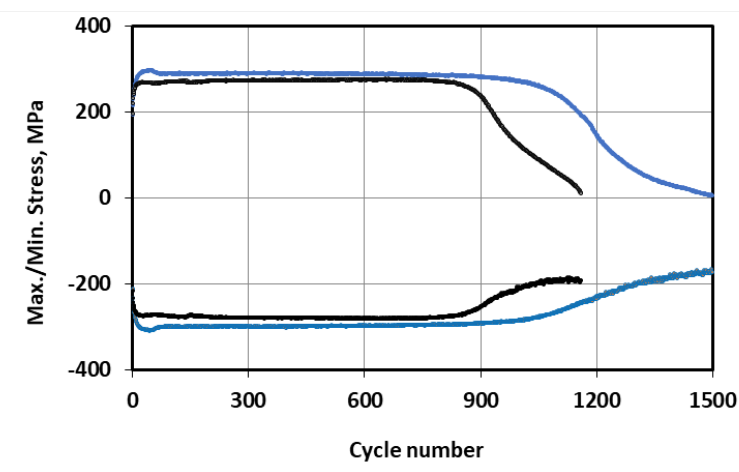

(a)

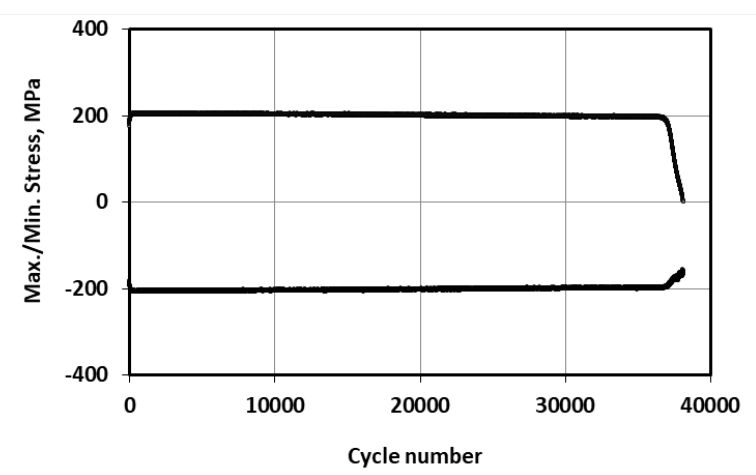

(c)

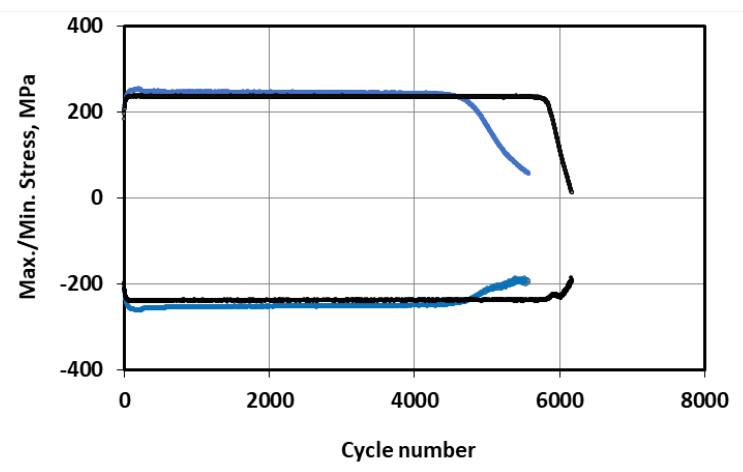

(b)

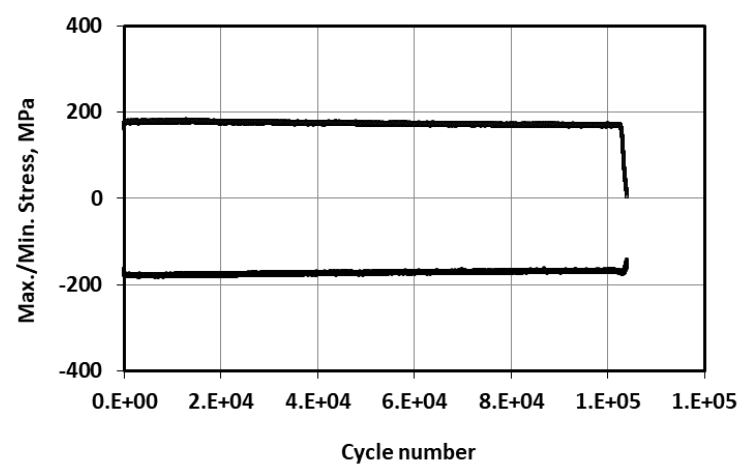

(d) 
Fig. 9. Maximum and minimum stresses of fatigue tests on ESR specimens with $\mathrm{S} / \mathrm{A}$ at $1100^{\circ} \mathrm{C}$ at $760^{\circ} \mathrm{C}$ at strain ranges of $1 \%(\mathbf{a}), \mathbf{0 . 6 \%}(\mathbf{b}), 0.4 \%$ (c), and $0.3 \%$ (d). The black and blue lines in (a) and (b) are duplicate tests of the same conditions.

All the fatigue tests at $760^{\circ} \mathrm{C}$ showed small cyclic hardening at the very beginning of the cycles. The maximum and minimum stresses showed insignificant cyclic hardening after the initial cycles.

The test specimens failed inside the gage length. A typical fatigue specimen after testing is pictured in Fig. 10.

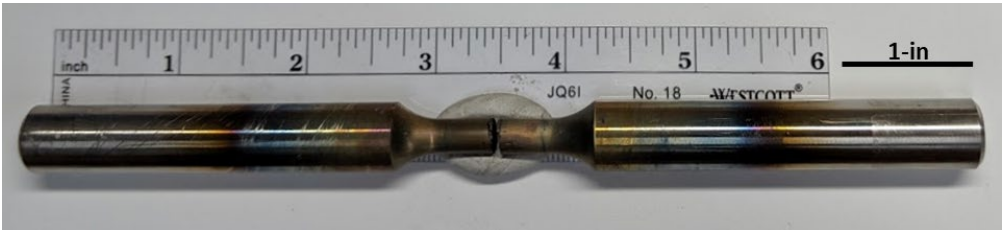

Fig. 10. An Alloy 709 fatigue specimen after testing.

The cycles to failure for the six fatigue tests are summarized in Table 6 . The criteria used for determining the cycles to failure were based on a $20 \%$ maximum load drop.

Table 6. Fatigue test results of ESR with $\mathrm{S} / \mathrm{A}$ at $1100^{\circ} \mathrm{C}$ at $760^{\circ} \mathrm{C}$.

\begin{tabular}{c|l|l|l}
\hline Test number & Specimen ID & $\begin{array}{c}\text { Strain } \\
\text { range, \% }\end{array}$ & \multicolumn{1}{|c}{ Cycles to failure* } \\
\hline 34339 & 3RBB1_4_C1-01 & $1 \%$ & 1,125 \\
\hline 34464 & 3RBB1_4_C1-03 & 1 & 918 \\
\hline 34371 & 3RBB1_4_C1-02 & 0.6 & 4,920 \\
\hline 34473 & 3RBB1_4_C1-04 & 0.6 & 5,903 \\
\hline 34492 & 3RBB1_4_C1-05 & 0.4 & 37,320 \\
\hline 34523 & 3RBB1_4_C1-06 & 0.3 & 103,310 \\
\hline 34574 & 3RBB1_4_C1-07 & 0.2 & Ongoing \\
\hline
\end{tabular}

*Failure criteria: $20 \%$ maximum load drop

\section{SUMMARY}

The planned FY 2019 creep testing at ORNL in support of the ASME code qualification of Alloy 709 is summarized in this report. Creep tests were started for $25 \mathrm{ESR}$ with S/A at $1100^{\circ} \mathrm{C}$ base metal specimens, for which 9 short-term creep rupture data sets were generated in this reporting cycle. The remaining 16 tests of ESR specimens with S/A at $1100^{\circ} \mathrm{C}$, along with the 6 long-term creep tests of AOD with S/A at $1100^{\circ} \mathrm{C}$, are ongoing.

A preliminary plan for fatigue testing was formulated for Alloy 709. Fatigue testing was initiated at $760^{\circ} \mathrm{C}$ on specimens machined from ESR with S/A at $1100^{\circ} \mathrm{C}$. The preliminary fatigue test results at strain ranges of $1,0.6,0.4$, and $0.3 \%$ are summarized in this report. 


\section{REFERENCES}

ASTM E139-11(2018), Standard Test Methods for Conducting Creep, Creep-Rupture, and Stress-

Rupture Tests of Metallic Materials, ASTM International, West Conshohocken, PA, 2018, www.astm.org

ASTM E606 / E606M-12, Standard Test Method for Strain-Controlled Fatigue Testing, ASTM International, West Conshohocken, PA, 2012, www.astm.org

McMurtrey, M., 2018 Report on the FY18 Creep Rupture and Creep-Fatigue Tests on the First Commercial Heat of Alloy 709, INL/EXT-18-46140, Idaho National Laboratory, August 2018.

Natesan, K., X. Zhang, T.-L. Sham, and H. Wang. 2017. Report on the Completion of the Procurement of the First Heat of Alloy 709, ANL-ART-89, Argonne National Laboratory, Lemont, IL, June 2017.

Wang, H., C. S. Hawkins, E. C. Disney and J. L. Moser. 2018. The Initiation of Long-Term Creep Rupture Tests on the First Alloy 709 Commercial Heat, ORNL/TM-2018/985, Oak Ridge National Laboratory, Oak Ridge, TN, September. 